\title{
Intellectual Capital Performance of Indonesian Banking Sector: A Modified VAIC (M-VAIC) Perspective
}

\author{
Ihyaul Ulum (Corresponding author) \\ University of Muhammadiyah Malang, Indonesia \\ E-mail:mas_ulum@yahoo.com \\ Imam Ghozali \\ Professor in Accounting, Diponegoro University, Indonesia
}

Agus Purwanto

Accounting Department, Diponegoro University, Indonesia

Received: April 20, 2014 Accepted: Sep. 21, 2014 Published: December 1, 2014

doi:10.5296/ajfa.v6i2.5246 URL: http://dx.doi.org/10.5296/ajfa.v6i2.5246

\begin{abstract}
The paper seeks to estimate and analize the Modified VAIC (M-VAIC) for measuring the value-based performance of the Indonesian banking sector for year of 2009-2012. M-VAIC is a comprehensive model to measure Intellectual Capital Performance (ICP) based on Value Added Intellectual Coefficient (VAIC ${ }^{\mathrm{TM}}$ ). The findings of this study indicate that the value of M-VAIC of Indonesian banking sector has a rather long range, which is between -21.41 until 5.20. Based on M-VAIC scores, performance of IC is classified into four, namely Top Performers, Good Performers, Performers Common, and Bad Performers. The results show that the ranking of three of the four state banks are on the Top Performers category. M-VAIC can be used to measure the ICP all of industries, not only banks. This is also reinforced by the results of the regression that indicate that the value added (VA) is a function of capital employed and the IC.
\end{abstract}

Keywords: Intellectual Capital Performance (ICP), M-VAIC, VAIC, Indonesian banking sector 


\section{Introduction}

Despite of the increasing recognition of the importance of Intellectual Capital (IC) in driving firm values and competitive advantages, accounting standards which regulate about IC is still limited. In Indonesia, implicitly IC has been recognized and discussed in the Statement of Financial Accounting Standards (PSAK) 19 (Ikatan Akuntan Indonesia, 2012) on intangible assets which is the adoption of International Accounting Standard (IAS) 38. In the standard, IC is not stated explicitly, but the components of IC (eg. goodwill) described how the accounting treatment. However, PSAK 19 does not regulate all of IC's components. Even, according to this standard, goodwill that generated internally should not be recognized as goodwill. In this regard, PSAK 22 on business combination which is the adoption of IFRS 3 states that goodwill arising from the acquisition is no longer be amortized but should be subject to an impairment test each year by way of testing which described in PSAK 48 on impairment of assets.

PSAK 19 states that an intangible asset is recognized if, and only if: 1) most likely the company will obtain future economic benefits from these assets, and 2) the cost of the asset can be measured reliably. This requirement is difficult to meet, so the intellectual capital to date can not be reported in the financial statements. This condition makes it difficult for the (potential) investors to be able to perform the analysis and assessment of the prospects of the company in the future based on the potential intellectual capital owned.

The limited provisions of IC accounting standards encourage the experts to make a measurement and reporting of IC models. The model which is very popular in many countries is Value Added Intellectual Coefficient (VAIC ${ }^{\text {TM}}$ ) developed by Pulic (1998). VAIC ${ }^{\text {TM }}$ does not measure IC it self, but it measures the impact of IC management (Ulum, 2009b; Ulum, Ghozali, \& Chariri, 2008). The assumption is, if a company has a good IC, and also managed well, there will be a good impact for the company. The impact was then measured by Pulic with VAIC ${ }^{\mathrm{TM}}$, thus VAIC ${ }^{\mathrm{TM}}$ is more properly called as intellectual capital performance (ICP) measurement which is by Mavridis (2004), Kamath (2007) and Ulum (2009a) called as busssines performance indicator (BPI).

Pulic (IBEC, 2003) state that two key resources in creating company's value added are capital employed and IC. IC consists of human capital and structual capital. Therefore Pulic then build his VAIC model consisting of three components, i.e. HCE (human capital efficiency), SCE (structural capital efficiency), and CEE (capital empoyed efficiency).

This paper offers additional component in calculating VAIC, namely RCE (relational capital efficiency). According to Brinker (1998), Stewart (1997), and Draper (1998), IC consist of three component, i.e. human capital, structural capital, customer/relational capital. On the other hand, Sveiby (1998) used the term of external structure, internal structure, and individual competence for all three components of IC. Thereby, the VAIC formulation added into four dimensions, HCE, SCE, RCE, and CEE are then called as M-VAIC model. 
Firer and Williams (2003) classify bank sector as one of highly incentive IC sectors. Hence, this paper evaluates the business performance of the Indonesian banking sector for year of 2009-2012. Financial reports of the banks for the relevant years, were used to obtain the data.

\section{Literature Review}

In Indonesia, research on IC in banking sector for example has been done by Ulum (2009a), Widarjo (2011), and Santoso (2011). Two last reviewed studies examined the effect of IC to company performance, while the first only measures the performance of IC based on the original formula of VAIC ${ }^{\mathrm{TM}}$. Relatively, It is also done by Basuki and Kusumawardhani (2012) and Sugiarti (2012).

In a somewhat different perspective, Razafindrambinina and Kariodimedjo (2011) analyzed the relationship of IC and corporate social responsibility disclosure. Later, Ulum (2013) proposed the performance measurement model for Islamic banking in Indonesia, which is constructed based on the VAIC ${ }^{\mathrm{TM}}$ model and labeled as iB-VAIC.

Brooking (1996) stated that the IC is the term given to a combination of intangible assets of markets, intellectual property, employees, and infrastructure that enables enterprises to be able to function. This definition clearly implied that IC is not just about human resources/human capital. Human capital is only one component of IC. Table 1 summarizes some of the constructs and definitions of IC offered by scholars:

Table 1. Constructs and definitions of IC

\begin{tabular}{|c|c|c|}
\hline Scholars & Constructs & Definition of IC \\
\hline Bontis (1996) & $\begin{array}{l}\text { Human capital Structural } \\
\text { capital Relational capital }\end{array}$ & $\begin{array}{l}\text { IC may provide a new resource-base for an } \\
\text { organization to compete and win }\end{array}$ \\
\hline $\begin{array}{l}\text { Roos and Roos } \\
\text { (1997) }\end{array}$ & $\begin{array}{l}\text { Human capital Structural } \\
\text { capital }\end{array}$ & $\begin{array}{l}\text { IC is the sum of the "hidden" assets of the } \\
\text { company, such as brands, trademarks and } \\
\text { patents and also includes all assets that are } \\
\text { not shown in the financial statements. IC is } \\
\text { a company's the most important source of } \\
\text { sustainable competitive advantages }\end{array}$ \\
\hline Stewart (1997) & $\begin{array}{l}\text { Human capital Structural } \\
\text { capital Customer capital }\end{array}$ & $\begin{array}{l}\text { IC is knowledge, information, intellectual } \\
\text { property and experience; it is a collective } \\
\text { brainpower or useful knowledge }\end{array}$ \\
\hline $\begin{array}{l}\text { Edvinsson and } \\
\text { Malone (1997) }\end{array}$ & $\begin{array}{l}\text { Human capital Structural } \\
\text { capital Customer capital }\end{array}$ & $\begin{array}{l}\text { IC refers to the difference between a } \\
\text { company's market value and book value }\end{array}$ \\
\hline Sveiby (1998) & $\begin{array}{l}\text { Personnel competence } \\
\text { Internal structure External }\end{array}$ & IC is knowledge that can be converted into \\
\hline
\end{tabular}


Bontis (1999) Human capital Structural IC is the effective use of knowledge as capital Relational capital opposed to information

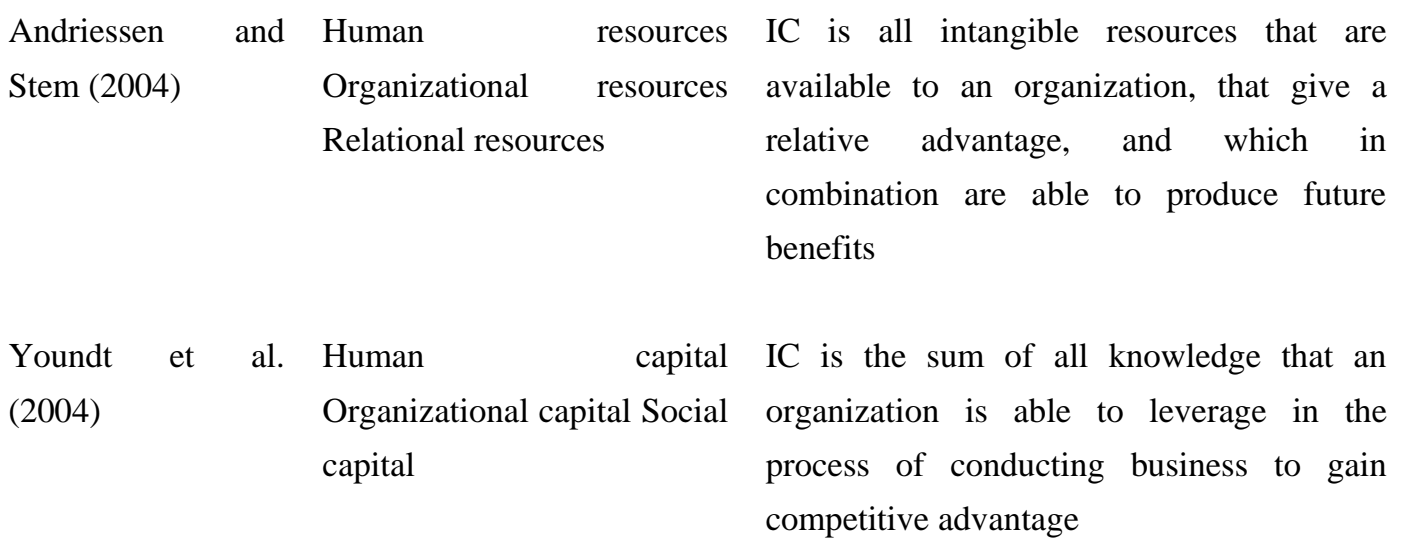

Source: Wang (2008)

\section{IC Valuation and Measurement Method}

There were several studies to investigate the valuation and measurement method of IC. Andriessen (2004) reviewed 25 methods for the valuation and measurement of intangibles. Table 2 summarizes the name of IC valuation and measurement method based on Andriessen's study and additional research.

Table 2. IC Valuation and Measurement Method

\begin{tabular}{|c|c|c|c|}
\hline No. & Name Of Method & Inventor/Pioneer & Year \\
\hline 1. & Balanced Scorecard & $\begin{array}{l}\text { Robert S. Kaplan and } \\
\text { David P. Norton }\end{array}$ & 1992 \\
\hline 2. & Calculated Intangible Value & $\begin{array}{l}\text { Thomas A. Stewart } \\
\text { David H. Luthy }\end{array}$ & $\begin{array}{l}1997 \\
1998\end{array}$ \\
\hline 3. & Citation-Weighted Patent & $\begin{array}{l}\text { Bronwyn H. Hall, Adam } \\
\text { B. Jaffe, } \\
\text { Manuel Trajtenberg }\end{array}$ & 2001 \\
\hline 4. & Holistic Value Approach & $\begin{array}{l}\text { Göran Roos, J. Roos, } \\
\text { Nicola C. Dragonetti, and } \\
\text { Leif Edvinsson }\end{array}$ & 1997 \\
\hline 5. & Intellectual Capital Audit & Annie Brooking & 1996 \\
\hline 6. & Intellectual Capital-Index & Göran Roos & 1997 \\
\hline
\end{tabular}


7. Inclusive Value Methodology

8. Intangible Asset Monitor

9. Intangibles Scoreboard

10. Intellectual Capital Benchmarking System

11. Intellectual Capital Dynamic Value

12. Intellectual Capital Statements

13. iValuing Factor

14. Market-To-Book Ratio

15. Skandia Navigator

16. Sullivan's Work

17. Value-Added Intellectual (VAIC)

18. Value Chain Scoreboard/ Value Chain Baruch Lev Blueprint

19. Extended VAIC

20. iB-VAIC
Philip K. M'Pherson and 2001

Stephan Pike

Karl Erick Sveiby

1997

Baruch Lev

1999

José Maria Viedma

1999, 2001

Ahmed Bounfour

2002

Jan Mouritsen

2001

Ken Standfield

2001

Thomas A. Stewart

1997

Leif Edvinsson and 1997

Michael S. Malone

Patrick H. Sullivan

1998, 2000

1997

2001, 2003

Jamal A. Nazari and Irene

2007

M. Herremans

Ihyaul Ulum

2013

Source: this study

\section{Value Added Intellectual Coefficient (VAIC ${ }^{\text {TM}}$ )}

VAIC $^{\text {TM }}$ model was developed by Pulic in 1997 that is designed to provide information about the value creation efficiency of tangible and intangible assets of the company. VAIC ${ }^{\text {TM }}$ is an instrument for measuring the performance of the company's intellectual capital. This approach is relatively easy and very possible to do, because it is constructed from the accounts in the financial statements (balance sheet, profit and loss).

Pulic (IBEC, 2003) states that there are two key resources to create added value in the enterprise: capital employed and IC. IC consists of human capital and structual capital. Value added is the output minus the input of a firm. Output is sales revenue; input is everything that comes from outside the company. Figure 1 illustrates the distribution of two key resources in question by Pulic (Andriessen, 2004). 

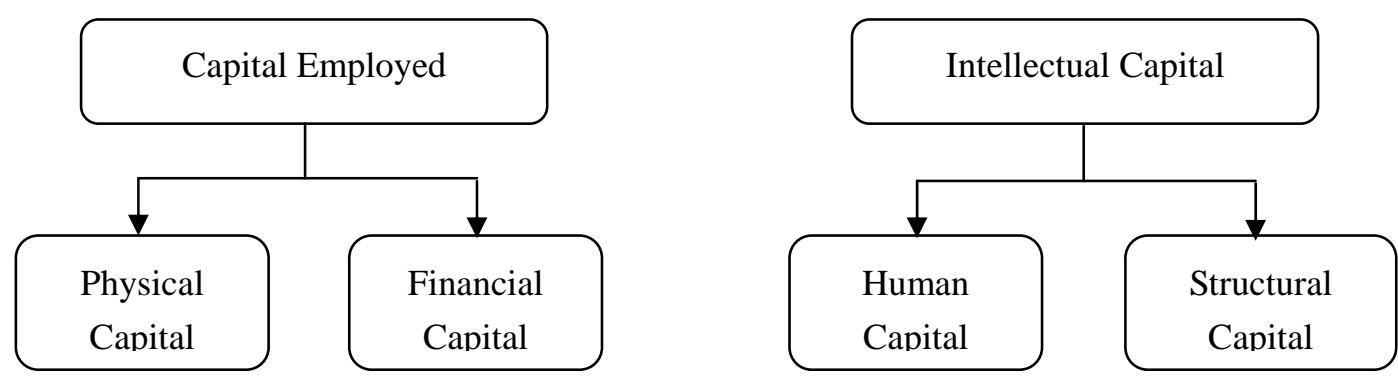

Source: Andriessen (2004)

Figure 1. Two key resources to create added value in the enterprise

This model begins with the company's ability to create value added (VA). Value added is the most objective indicator to assess the success of the business and demonstrate the ability of the company in the creation of value (value creation). VA is calculated as the difference between output and input. Output (OUT) represents the revenue and includes all products and services sold in the market, while the input (IN) covers the entire load used in obtaining revenue. It is important in this model is that the burden of employees (labor expenses) are not included in IN. Because of its active role in the process of value creation, intellectual potential (which is represented by labor expenses) is not counted as an expense (cost) and are not included in the IN component. Therefore, a key aspect of the model is to treat labor Pulic as entity creation of value (value creating entity).

VA is influenced by the efficiency of the Human Capital (HC) and Structural Capital (SC). Other relationships of VA is capital employed (CE), which in this case is labeled with CEE. CEE is an indicator for the VA created by one unit of physical capital. Pulic (1998) assumed that if 1 unit of CE produced greater returns than any other company, it means the company better utilize its CE. Thus, a better utilization of CE is part of the company's IC. The next relationship is VA and HC. 'Human Capital Efficiency' (HCE) shows how much the VA can be produced with funds expended for labor. Relationship between VA and HC indicate the ability of HC to create value in the company. Consistent with the views of other writers IC, Pulic argued that the total salary and wage costs are an indicator of the company HC.

The third relationship is 'structural capital efficiency' (SCE), which shows the contribution of structural capital (SC) in value creation. SCE measured the amount of SC required to produce 1 rupiah from VA and is an indication of how successful the SC in value creation (Tan, Plowman, \& Hancock, 2007). SC is not an independent measure as HC, it is dependent on value creation (Pulic, 2000c). That is, the greater the contribution of HC in value creation, the smaller the contribution of the SC in the case. Pulic further stated that SC is VA minus HC, this model has been verified through empirical research on traditional industrial sectors (Pulic, 2000b). 


\section{Macrothink

The advantage of VAIC ${ }^{\mathrm{TM}}$ method is because the required data is relatively easily obtained from various sources and types of companies. The data required to calculate the various ratios are financial figures that are generally available standard of corporate financial statements (Tan et al., 2007). The other alternative of IC measurements only limited on financial indicators and unique non-financial perspective that only to supplement a company's individual profile. These indicators, especially indicators of non-financial, are not available or not recorded by other companies. Consequently, the ability to implement the measurements consistently with a large and diversified sample is limited (Firer \& Williams, 2003).

VAIC has been used in studies in several countries in a variety of research designs. For example, VAIC used to measure the IC performance of a company (Kamath, 2007; Mavridis, 2004; Ulum, 2009a); the influence of VAIC on firm's performance is also widely studied (Kamal, Mat, Rahim, Husin, \& Ismail, 2011; Khanqah, Khosroshahi, \& Ghanavati, 2012; Shiri, Mousavi, Pourreza, \& Ahmadi, 2012; Sydler, Haefliger, \& Pruksa, 2013); antecedent factors of VAIC also been widely studied (Al-Musalli \& Ismail, 2012; El-Bannany, 2008; Saleh, Rahman, \& Hassan, 2009).

\section{Modified VAIC (M-VAIC)}

M-VAIC is a comprehensive measure of IC based on VAICTM model. It is started with calculating VA by using the formula proposed by Pulic (2000a):

$V A=O P+E C+D+A$

Where OP is operating profit, EC is employee costs, D is depreciation, and A is amortisation. According to Pulic (2004), VAIC ${ }^{\mathrm{TM}}$ is the sum of intellectual capital efficiency (ICE) and capital employed efficiency (CEE), while ICE is HCE (human capital efficiency) plus SCE (structural capital efficiency). The formula to calculate HCE is as follows:

$H C E=V A / H C($ Pulic, 2000a $)$

- $\mathrm{HCE}=$ Human Capital Efficiency: ratio of VA to HC.

- $\mathrm{VA}=$ value added

- $\mathrm{HC}=$ Human Capital: total salaries and wages.

SCE $=$ SC/VA(Pulic, 2000a)

- $\mathrm{SCE}=$ Structural Capital Efficiency: ratio of SC to VA

- $\mathrm{SC}=$ Structural Capital : VA-HC

While in this M-VAIC, I add the third component of IC, i.e. RCE (relational capital efficiency). RCE illustrate the efficiency of investment in relational aspect. In this context, relational capital is proxied by marketing costs.

$R C E=R C / V A($ this study)

- $\mathrm{RCE}=$ Relational Capital Efficiency: ratio of RC to VA 


\section{Macrothink

- $\mathrm{RC}=$ Relational Capital: marketing costs (Nazari \& Herremans, 2007)

Pulic (2004) argued that to have a broad overview of the efficiency of all resources, it is important to take the financial capital and physical capital (capital employed) as one of the considerations. The efficiency of capital employed calculated by:

$C E E=V A / C E($ Pulic, 2000a)

- $\mathrm{CEE}=$ Capital Employed Efficiency: ratio of VA to CE

- $\mathrm{CE}=$ Capital Employed: book value of total assets.

Thus, the complete formula of M-VAIC is:

$\mathrm{M}-\mathrm{VAIC}=\mathrm{ICE}+\mathrm{CEE}$

$\mathrm{ICE}=\mathrm{HCE}+\mathrm{SCE}+\mathrm{RCE}$

$\mathrm{M}-\mathrm{VAIC}=\mathrm{HCE}+\mathrm{SCE}+\mathrm{RCE}+\mathrm{CEE}$

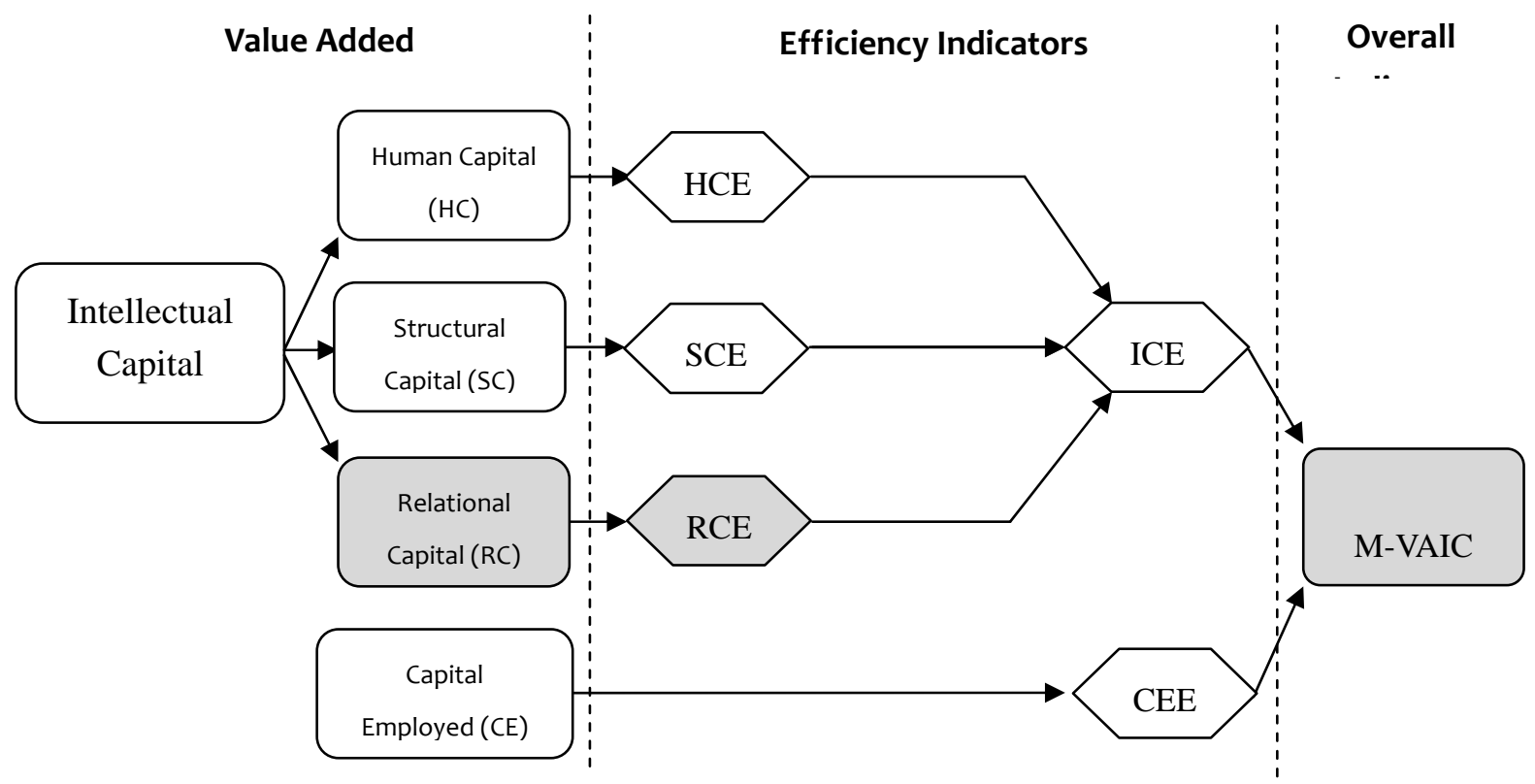

Source: modified from Laing, Dunn, and Hughes-Lucas (2010)

Figure 2. The Formulation of M-VAIC

\section{Indonesian Bank}

Banks are special and therefore must run business based on prudential principles. The functions of banks in Indonesia are basically as financial intermediary that take deposits from surplus units and channel financing to deficit units. According to Indonesian banking law, Indonesian banking institutions are typically classified into commercial and rural banks. Commercial banks differ with rural banks in the sense that the latter do not involve directly in 
payment system and have restricted operational area. In term of operational definition, bank in Indonesia are classified into non-syariah and syariah-based principles commercial banks.

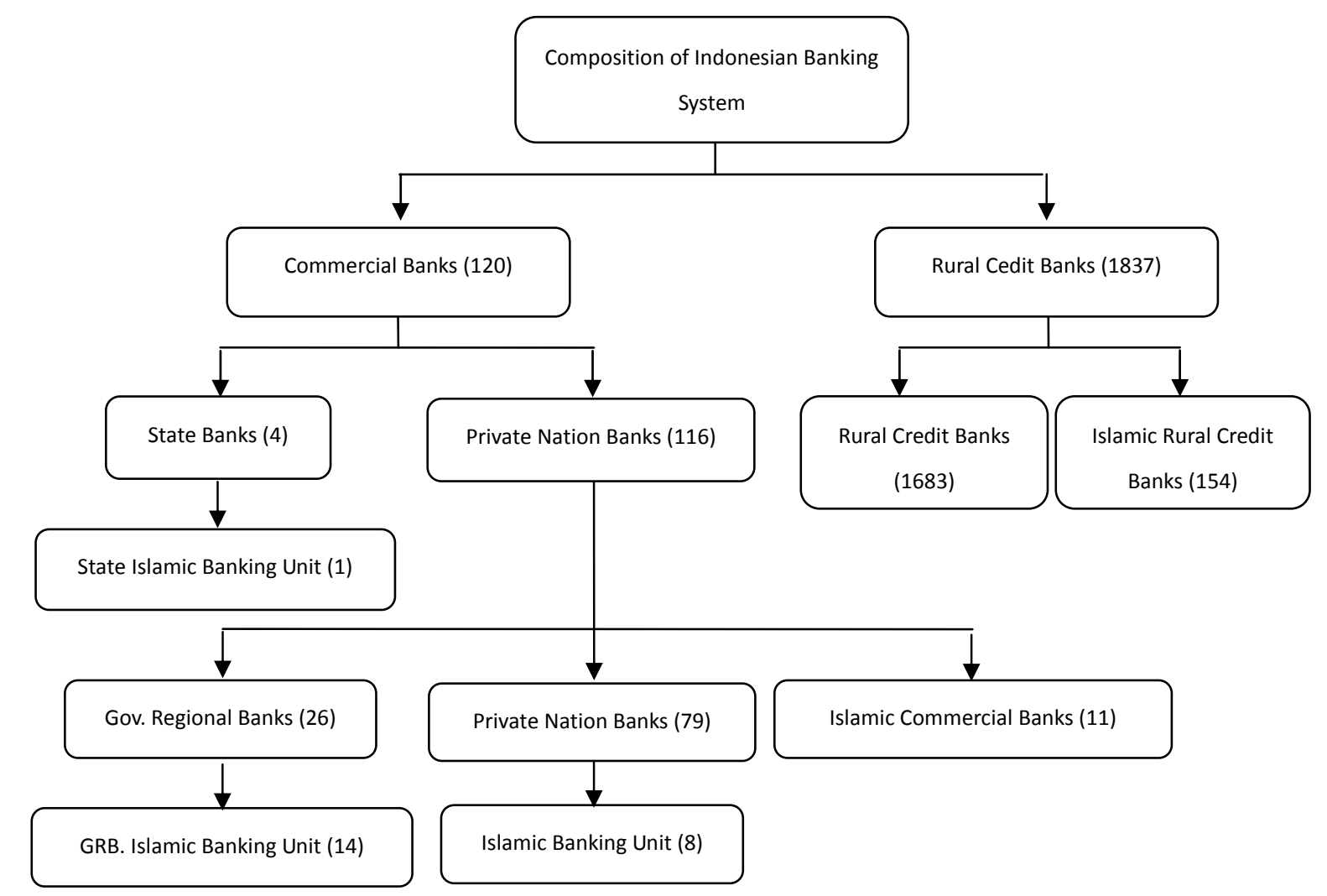

Source: www.bi.go.id

Figure 3. Recapitulation of Banking Institutions in Indonesia

In view of providing a wider banking services alternative to Indonesian economy, the development of Islamic banking in Indonesia is implemented under dual banking system in compliance with the Indonesian Banking Architecture (API). Islamic banking and conventional banking systems jointly and synergically support a wider public fund mobilization in the framework of fostering financing capability of national economic sectors.

The characteristic of Islamic banking operation is based on partnership and mutual benefits principle provides an alternative banking system with mutual benefits both for the public and the bank. This system will give priorities to aspects related to fairness in transaction and ethical investment by underlining the values of togetherness and partnership in production, and by avoiding any speculative activity in financial transaction. By providing various products and banking services supported by variative financial scheme,.Islamic banking will be a credible alternative that can be benefited by all of Indonesian people without exception. 


\section{Macrothink}

\section{Method}

Data were drawn from financial reports of Indonesian banks for the year of 2012. A review was conducted of the international literature on intellectual capital with specific reference to literature that reviews measurement techniques and tools, and the M-VAIC method is applied in order to analyze the data. The result of calculating M-VAIC then used to make a rank of Bussiness Performance Indicator (BPI) of Indonesian banking sector.

The phases in calculating BPI using M-VAIC method:

Phase I: Calculating Value Added (VA)

$V A=O P+E C+D+A($ Pulic, 2000a)

Phase II: Calculating the efficiency of IC (ICE)

- $\quad I C E=H C E+S C E+R C E($ this study)

- $\quad H C E=V A / H C($ Pulic, 2000a)

- $\quad$ SCE = SC/VA(Pulic, 2000a)

- $\quad R C E=R C / V A($ this study)

Phase III: Calculating the efficiency of capital employed (CEE)

CEE $=$ VA/CE(Pulic, 2000a $)$

Phase IV: deriving of M-VAIC

- $\quad \mathrm{M}-\mathrm{VAIC}=\mathrm{ICE}+\mathrm{CEE}$ (this study)

- $\quad \mathrm{M}-\mathrm{VAIC}=\mathrm{HCE}+\mathrm{SCE}+\mathrm{RCE}+\mathrm{CEE}$ (this study)

Note about Abbreviation:

- M-VAIC : Modified VAIC

- ICE: Intellectual Capital Efficiency

- HCE : Human Capital Efficiency

- SCE: Structural Capital Efficiency

- RCE: Relational Capital Efficiency

- CEE: Capital Employed Efficiency

- VA: Value Added

- HC: Human Capital; all the expenses on compensation and development of employees

- SC: Structural Capital; VA - HC

- RC: Relational Capital; marketing cost 
- CE: Capital Employed; book value of total assets.

- OP: Operating Profit

- EC: Employee Costs

- D: Depreciation

- A: Amortisation

Phase V: Since the value added (VA) in any organization is a function of capital employed and the IC, the four regression are run using VA as the dependent variable and $\mathrm{HC}$, SC, RC, and $\mathrm{CE}$ as an independent variables.

Phase VI: make a ranking for Indonesian bank based on intellectual capital performace measured with M-VAIC.

\section{Findings and Discussion}

Table 3 presents the mean values of each of the components forming the M-VAIC, namely HC, SC, RC, CE, and VA. During the four years observation, the data in Table 3 show a consistent increase each year. Total assets of the company (CE) have the most significant improvement compared with the other four components.

Table 3. Mean of HC, SC, RC, CE, and VA (in million Rupiah)

\begin{tabular}{|c|c|c|c|c|}
\hline & 2009 & 2010 & 2011 & 2012 \\
\hline $\mathrm{HC}$ & $1,109,297.10$ & $1,277,234.00$ & 1,391,169.61 & $1,678,457.31$ \\
\hline SC & $1,421,147.10$ & $2,054,545.61$ & 2,535,499.39 & 2,935,841.19 \\
\hline $\mathrm{RC}$ & $108,830.00$ & $139,112.45$ & $139,545.13$ & $150,988.00$ \\
\hline CE & $6,537,039.31$ & $7,989,524.81$ & $11,549,977.53$ & $13,729,594.02$ \\
\hline VA & $2,530,444.21$ & 3,331,779.61 & 3,926,669.00 & $4,614,298.51$ \\
\hline
\end{tabular}

Note: HC: Human Capital; SC: Structural Capital ; RC: Relational Capital ; CE: Capital Employed; VA: Value Added

Table 4 presents the mean value of the information HCE, SCE, RCE, CEE, and M-VAIC. During the study period, the efficiency of each M-VAIC components is fluctuated. Consequently, scores of M-VAIC also looked up and down from year to year. In 2010 and 2012, M-VAIC scores are on 2.7 points, while in 2009 and 2010 only in the range of 2.2 2.3. 
Table 4. Mean of HCE, SCE, RCE, CEE, and M-VAIV

\begin{tabular}{lcccc}
\hline Category & $\mathbf{2 0 0 9}$ & $\mathbf{2 0 1 0}$ & $\mathbf{2 0 1 1}$ & $\mathbf{2 0 1 2}$ \\
\hline HCE & 1.50 & 1.92 & 2.14 & 2.03 \\
SCE & 0.38 & 0.48 & -0.41 & 0.37 \\
RCE & 0.06 & 0.05 & 0.16 & 0.07 \\
CEE & 0.39 & 0.29 & 0.32 & 0.30 \\
M-VAIC & 2.33 & 2.74 & 2.21 & 2.78 \\
Note: HCE: & Human Capital Efficiency; SCE: Structural Capital Efficiency; RCE: Relational \\
Capital & Efficiency; CEE: Capital & Employed & Efficiency; M-VAIC: Modified Value Added \\
Intellectual Coefficient. & & \\
\hline
\end{tabular}

To prove that the VA is a function of each of the components forming the performance of ICs in the formula M-VAIC, four regressions is done by placing the VA as the dependent variable and each of the components (HC, SC, RC, CE) as the independent variable. This test refers to Kamath (2007) who did the same way when measured the performance of IC banking in India using the $\mathrm{VAIC}^{\mathrm{TM}}$ model.

Table 5 shows that the value of $\mathrm{R}^{2}$ of the entire test is at a high enough rate (0.836-0.994) except for testing the RC and VA. This means the contribution of these components is more than $80 \%$. Special to the RC, the value of R2 is in the range between $0.461-0.665$. This figure is relatively smaller than other components because the number of investment in the relational capital aspects which is proxied by the marketing costs are not too large (on average between 108.830 to 150.988 million rupiah). The Regression results which shown in Table 5 confirms that the variables used in this study can be relied upon to draw conclusions. 
Table 5. Regression results

\begin{tabular}{|c|c|c|c|c|}
\hline & 2009 & 2010 & 2011 & 2012 \\
\hline \multicolumn{5}{|c|}{$H C$ and VA } \\
\hline Slope & 2.562 & 2.907 & 2.114 & 3.261 \\
\hline Intercept & -311551.387 & -380829.883 & -329355.552 & -859565.637 \\
\hline $\mathrm{t}$ & 23.999 & 27.288 & 19.431 & 29.178 \\
\hline $\mathrm{R}^{2}$ & 0.955 & 0.963 & 0.929 & 0.966 \\
\hline \multicolumn{5}{|c|}{ SC and VA } \\
\hline Slope & 1.569 & 1.481 & 0.935 & 1.412 \\
\hline Intercept & 301354.319 & 289155.236 & 240661.261 & 468795.379 \\
\hline $\mathrm{t}$ & 40.369 & 55.120 & 31.477 & 69.331 \\
\hline $\mathrm{R}^{2}$ & 0.984 & 0.991 & 0.972 & 0.994 \\
\hline \multicolumn{5}{|c|}{$R C$ and $V A$} \\
\hline Slope & 16553.859 & 22.371 & 16.996 & 27.402 \\
\hline Intercept & 231170.231 & 219756.018 & 239350.650 & 476871.412 \\
\hline $\mathrm{t}$ & 4.809 & 7.593 & 6.545 & 6.843 \\
\hline $\mathrm{R}^{2}$ & 0.461 & 0.665 & 0.596 & 0.610 \\
\hline \multicolumn{5}{|c|}{$C E$ and VA } \\
\hline Slope & 0.421 & 0.477 & 0.202 & 0.314 \\
\hline Intercept & -219627.668 & -482427.308 & 275045.377 & 304271.679 \\
\hline $\mathrm{t}$ & 18.364 & 18.273 & 12.175 & 14.944 \\
\hline $\mathrm{R}^{2}$ & 0.926 & 0.920 & 0.836 & 0.882 \\
\hline
\end{tabular}

Based on M-VAIC scores, the performance of IC state banks in Indonesia looked better than the private national banks. During the four years of observation, the banks owned by 


\section{Macrothink}

government are always in the top ten best performance of IC based on M-VAIC. In the category of private national banks, there are two banks that having excellent performance, namely Bank Pan Indonesia (PNBN) and Bank Central Asia (BBCA). Table 6 show top ten of ICP based on M-VAIC.

Table 6. The top ten of M-VAIC score

\begin{tabular}{lllll}
\hline No. & $\mathbf{2 0 0 9}$ & $\mathbf{2 0 1 0}$ & $\mathbf{2 0 1 1}$ & $\mathbf{2 0 1 2}$ \\
\hline 1. & PNBN & PNBN & PNBN & PNBN \\
2. & BBCA & BMRI & BBCA & BBCA \\
3. & BMRI & BBCA & BMRI & BBRI \\
4. & BBRI & BBRI & BVIC & BMRI \\
5. & BBNI & BVIC & BSWD & BSWD \\
6. & BDMN & MEGA & BBRI & BBNI \\
7. & BTPN & BSWD & BBKP & BTPN \\
8. & BAEK & BBNI & BNGA & MEGA \\
9. & NISP & BDMN & BTPN & BDMN \\
10. & BBTN & BNGA & BBNI & BJTM
\end{tabular}

Note: Bank codes based on the code that formally used in the Indonesia Stock Exchange. The list of abbreviations code of banks is presented in the appendix at the end of the paper.

Each bank's result are sorted on the basis of M-VAIC performance and classified to four category as follows:

1) Top performers -M-VAIC score of above 3.50

2) Good performers -M-VAIC score of between 2.5 and 3.49

3) Common performers -M-VAIC score of between 1.5 and 2.49

4) Bad performers -M-VAIC score of below 1.5.

Table 7 and 8 present list of banks included in the the category of Top Performers and Bad Performers. In the group of banks with the best performance of IC, banks that are very 
popular in Indonesia seemed quite dominate in the top rankings, e.g. Bank Central Asia (BBCA), Bank Mandiri (BMRI), and Bank Rakyat Indonesia (BBRI). On the other hand, in the group of banks with Bad Performers category is dominated by private national banks.

Three of the four state banks in Indonesia can enter the Top Performers in the group, namely BMRI, BBRI, and BBNI. Three of the four state banks in Indonesia, including the Top Performers in the group, namely BMRI, BBRI, and BBNI. This finding is interesting because there has been an assumption that the state-owned banks have difficulties to compete with other companies because of the high bureaucracy, political pressure from many parties, high social obligations, a huge work force, poor image, and low efficiency (Kamath, 2007). This research proves that the state banks can compete and even has a very good performance of IC.

Table 7. Banks with 'Top Performers’ in the survey

\begin{tabular}{lllll}
\hline No. & $\mathbf{2 0 0 9}$ & $\mathbf{2 0 1 0}$ & $\mathbf{2 0 1 1}$ & $\mathbf{2 0 1 2}$ \\
\hline 1. & PNBN & PNBN & PNBN & PNBN \\
2. & BBCA & BMRI & BBCA & BBCA \\
3. & BMRI & BBCA & BMRI & BBRI \\
4. & BBRI & BBRI & BVIC & BMRI \\
5. & - & BVIC & BSWD & BSWD \\
6. & - & MEGA & BBRI & BBNI \\
7. & - & BSWD & BBKP & BTPN \\
8. & - & - & BNGA & MEGA \\
9. & - & - & BTPN & - \\
10. & - & - & & -
\end{tabular}

Note: Bank codes based on the code that formally used in the Indonesia Stock Exchange. The list of abbreviations code of banks is presented in the appendix at the end of the paper.

The prominent bank during the observation is Bank Pan Indonesia (PNBN), or known as Panin bank. For four years in a row, the ICP of Panin bank is at the top beating other banks. PNBN was founded in 1971 and has had 496 branches in 2012. Their advantage is the ability 


\section{Al Macrothink Institute ${ }^{\mathrm{TM}}$}

to manage their employees very well. High Scor of M-VAIC largely contributed from HCE scores that is an efficiency of human capital. Panin Bank managed to exploit the employees's capabilities in a medium investment. This appears to be linear with the development strategy of employees (human capital) which states:

"Embrace and enhance corporate culture to fully recognize individual achievements and continue motivating our staff towards better customer service and higher productivity” (Bank Panin, 2012, p. 3).

Table 8. Banks with 'Bad Performers' in the survey

\begin{tabular}{lllll}
\hline No. & $\mathbf{2 0 0 9}$ & $\mathbf{2 0 1 0}$ & $\mathbf{2 0 1 1}$ & $\mathbf{2 0 1 2}$ \\
\hline 1. & INPC & BABP & BKSW & BEKS \\
2. & BKSW & BKSW & BEKS & INPC \\
3. & BABP & AGRO & BABP & BABP \\
4. & AGRO & BEKS & - & BKSW \\
5. & BNII & - & - & - \\
6. & BEKS & - & - & -
\end{tabular}

Note: Bank codes based on the code that formally used in the Indonesia Stock Exchange. The list of abbreviations code of banks is presented in the appendix at the end of the paper.

In the list of banks in the group Bad Performers, there are three private banks that consistently came in last, the bank's Indonesia (BEKS), Bank Kesawan (BKSW), and Bank ICB Bumiputera (BABP). The three banks for four years of observation have a score of M-VAIC under 1.50, even minus (-). In 2012, the total amount of capital employed (CE) three banks only $1.9 \%$ of Bank Mandiri (BMRI). Similarly, the total score of value added (VA) three banks is only 2.16\% of Bank Rakyat Indonesia (BBRI).

With relatively limited capital, these banks are quite difficult to develop a network. This can be seen from the number of BEKS branch offices in 2012 that only 48, BABP 16, and BKSW only 14 branch offices. In fact, BEKS for three consecutive years (2009-2011) suffered the loss, while BKSW also suffered losses in 2012. 


\section{Concluding Remarks}

The term IC emphasizes a combination of intellect and capital to show the importance of knowledge (Serenko \& Bontis, 2013). Over the past few years, the company concentrate its management activities on tangible and financial assets (Bellora \& Guenther, 2013), but recently they began to spread attention to the issue of intangible assets such as human capital and innovation capital (Lev, 2001; OECD, 2010). In this context, the use of M-VAIC becomes quite relevant to measure the performance of IC.

The use of M-VAIC to measure the ICP of Indonesia banking is the first study that has been done. The addition of RCE as a third components in the VAIC method is believed to further increase the power of this method in measuring and predicting the ICP. This is proven by regression results showing that VA is a function of the HC, SC, RC, and CE with $\mathrm{R}^{2}$ values that are highly significant (0.836-0.994) except for testing the RC and VA. This means that these components contribute more than $80 \%$.

Based on the score of M-VAIC known that three of the four state banks are on the Top Performers category, namely BMRI, BBRI, and BBNI. This finding is interesting because there has been an assumption that the state-owned banks have difficulties to compete with other companies because of the high bureaucracy, political pressure from many parties, high social obligations, a huge work force, poor image, and low efficiency (Kamath, 2007). This research proves that the state banks can compete and even has a very good performance of IC

Thus, it can be concluded that the M-VAIC can be used to measure the performance of IC companies, not only banks. This paper can be used as a benchmark to measure the performance of the company from the aspect of innovation, their ability to manage the CE and IC that they have to win the competition. Future studies could develop study based on this paper not just on the banking sector, because the M-VAIC can be implemented across all industry sectors.

\section{References}

Al-Musalli, M. A. K., \& Ismail, K. N. I. K. (2012). Corporate Governance, Bank Specific Characteristics, Banking Industry Characteristics, and Intellectual Capital (IC) Performance of Banks In Arab Gulf Cooperation Council (GCC) Countries. Asian Academy of Management Journal of Accounting and Finance, 8(Supp. 1), 115-135.

Andriessen, D. (2004). Making sense of intellectual capital : designing a method for the valuation of intangibles. Jordan Hill, Oxford, UK: Elsevier, Inc.

Bank Panin. (2012). Annual Report 2012.

Basuki, \& Kusumawardhani, T. (2012). Intellectual Capital, Financial Profitability, and Productivity: An Exploratory Study of the Indonesian Pharmaceutical Industry. Asian Journal of Business and Accounting 5(2), 41-68.

Bellora, L., \& Guenther, T. W. (2013). Drivers of innovation capital disclosure in intellectual capital statements: Evidence from Europe. The British Accounting Review, 1-16. 
Brinker, B. (1998). Intellectual capital: Tomorrow's asset, today's challenge. Retrieved 15 December, 2006, from http://www.cpavision.org/vision/wpaper05b.cfm

Brooking, A. (1996). Intellectual Capital: Core Assets for the Third Millennium. London: Enterprise Thomson Business Press.

Draper, T. (1998). Measuring intellectual capital: Formula for disaster. Retrieved November, 2007, from http://www.drapervc.com/Hoover.html

El-Bannany, M. (2008). A study of determinants of intellectual capital performance in banks: the UK case. Journal of Intellectual Capital, 9(3), 487-498. http://dx.doi.org/10.1108/14691930810892045

Firer, S., \& Williams, S. M. (2003). Intellectual capital and traditional measures of corporate performance. Journal of Intellectual Capital, 4(3), 348-360. http://dx.doi.org/10.1108/14691930310487806

IBEC. (2003). Intellectual capital: efficiency in Croatian economy. London: IBEC.

Ikatan Akuntan Indonesia. (2012). Standar Akuntansi Keuangan. Jakarta: Ikatan Akuntan Indonesia.

Kamal, M. H. M., Mat, R. C., Rahim, N. A., Husin, N., \& Ismail, I. (2011). Intellectual Capital and Firm Performance of Commercial Banks In Malaysia. Asian Economic and Financial Review, 2(4), 577-590.

Kamath, G. B. (2007). The intellectual capital performance of Indian banking sector. Journal of Intellectual Capital, 8(1), 96-123. http://dx.doi.org/10.1108/14691930710715088

Khanqah, V. T., Khosroshahi, M. A., \& Ghanavati, E. (2012). An Empirical Investigation of the Impact of Intellectual Capital on Firms ' Market Value and Financial Performance: Evidence from Iranian Companies. International Journal of Management Business Research, 2(1), 1-12.

Laing, G., Dunn, J., \& Hughes-Lucas, S. (2010). Applying the VAIC ${ }^{\text {TM }}$ model to Australian Hotels. Journal of Intellectual Capital, 11(3), 269-274. http://dx.doi.org/10.1108/14691931011064545

Lev, B. (2001). Intangibles: management, measurement, and reporting. Washington: The Brookings Institution.

Mavridis, D. G. (2004). The intellectual capital performance of the Japanese banking sector. Journal of Intellectual Capital, 5(3), 92-115. http://dx.doi.org/10.1108/14691930410512941

Nazari, J. A., \& Herremans, I. M. (2007). Extended VAIC model measuring intellectual capital components. Journal of Intellectual Capital 8(4), 595-609. http://dx.doi.org/10.1108/14691930710830774

OECD. (2010). The OECD innovation strategy - Getting a head start on tomorrow. Retrieved November, 2013, from 
http://www.oecd-ilibrary.org/science-andtechnology/the-oecd-innovation-strategy_97892640 83479-en

Pulic, A. (1998). Measuring the Performance of Intellectual Potential in Knowledge Economy. Paper presented at the the 2nd McMaster World Congress on Measuring and Managing Intellectual Capital, Austria.

Pulic, A. (2000a). Basic information on VAIC ${ }^{\text {TM }}$ Retrieved December 2000, from www.vaic-on.net.

Pulic, A. (2000b). MVA and VAIC ${ }^{\mathrm{TM}}$ Analysis of randomly selected companies from FTSE 250. Austrian Intellectual Capital Research Center. Graz - London.

Pulic, A. (2000c). VAIC: an accounting tool for IC management. International Journal of Technology Management, 20(5-8), 702-714. http://dx.doi.org/10.1504/IJTM.2000.002891

Pulic, A. (2004). Intellectual capital - does it create or destroy value? . Measuring Business Excellence, 8(1), 62-68. http://dx.doi.org/10.1108/13683040410524757

Razafindrambinina, D., \& Kariodimedjo, D. (2011). Is Company Intellectual Capital Linked to Corporate Social Responsibility Disclosure? Findings from Indonesia. Communications of the IBIMA. doi: 10.5171/2011

Saleh, N. M., Rahman, M. R. C. A., \& Hassan, M. S. (2009). Ownership Structure and Intellectual Capital Performance In Malaysia. Asian Academy of Management Journal of Accounting and Finance, 5(1), 1-29.

Santoso, E. (2011). Intellectual Capital In Indonesia: The Influence on Financial Performance of Banking Industry. University of Phoenix.

Serenko, A., \& Bontis, N. (2013). Investigating the current state and impact of the intellectual capital academic discipline. Journal of Intellectual Capital, 14(4), 476-500. http://dx.doi.org/10.1108/JIC-11-2012-0099

Shiri, M. M., Mousavi, K., Pourreza, A., \& Ahmadi, S. (2012). The Effect of Intellectual Capital on Market Value Added. Journal of Basic and Applied Scientific Research, 2(7), 7214-7226.

Stewart, T. A. (1997). Intellectual Capital. London: Nicholas Brealey Publishing.

Sugiarti, Y. (2012). Kinerja Intellectual Capital Perbankan Indonesia: Penerapan Model Pulic dan Analisis Panel Data. Jurnal Keuangan dan Perbankan, 16(2), 304-317.

Sveiby, K. E. (1998). Measuring Intangibles and Intellectual Capital - An Emerging First Standard. Queensland: Queensland University of Technology.

Sydler, R., Haefliger, S., \& Pruksa, R. (2013). Measuring intellectual capital with financial figures: Can we predict firm profitability? European Management Journal. 


\section{Macrothink}

Asian Journal of Finance \& Accounting ISSN 1946-052X 2014, Vol. 6, No. 2

Tan, H. P., Plowman, D., \& Hancock, P. (2007). Intellectual capital and financial returns of companies. Journal of Intellectual Capital, 8(1), 76-95. http://dx.doi.org/10.1108/14691930710715079

Ulum, I. (2009a). Intellectual Capital Performance Sektor Perbankan di Indonesia. Jurnal Akuntansi dan Keuangan (Terakreditasi Dikti), 10(2), 77-84.

Ulum, I. (2009b). Intellectual Capital; Konsep dan Kajian Empiris. Yogyakarta: PT. Graha Ilmu.

Ulum, I. (2013). iB-VAIC: Model Pengukuran Kinerja Intellectual Capital Perbankan Syariah di Indonesia. Inferensi (Terakreditasi Dikti), 7(1), 183-204.

Ulum, I., Ghozali, I., \& Chariri, A. (2008). Intellectual capital dan kinerja keuangan perusahaan; sebuah analisis dengan pendekatan partial least squares. Paper presented at the Simposium Nasional Akuntansi XI, Universitas Tanjung Pura, Pontianak.

Wang, J. C. (2008). Investigating market value and intellectual capital for S\&P 500. Journal of Intellectual Capital, 9(4), 546-563. http://dx.doi.org/10.1108/14691930810913159

Widarjo, W. (2011). Pengaruh Modal Intelektual dan Pengungkapan Modal Intelektual pada Nilai Perusahaan. Jurnal Akuntansi dan Keuangan Indonesia.

Apendix: The list of abbreviations code of banks

\begin{tabular}{|l|l|l|}
\hline No & Code & Nama of Bank \\
\hline 1 & AGRO & Bank Rakyat Indonesia Agro Niaga Tbk \\
\hline 2 & BABP & Bank ICB Bumi Putra Tbk \\
\hline 3 & BACA & Bank Capital Indonesia Tbk \\
\hline 4 & BAEK & Bank Ekonomi Raharja Tbk \\
\hline 5 & BBCA & Bank Central Asia Tbk \\
\hline 6 & BBKP & Bank Bukopin Tbk \\
\hline 7 & BBNI & Bank Negara Indonesia (Persero)Tbk \\
\hline 8 & BBNP & Bank Nusantara Parahyangan Tbk \\
\hline 9 & BBRI & Bank Rakyat Indonesia (Persero)Tbk \\
\hline 10 & BBTN & Bank Tabungan Negara (Persero) Tbk \\
\hline 11 & BCIC & Bank Mutiara Tbk \\
\hline 12 & BDMN & Bank Danamon Indonesia Tbk \\
\hline 13 & BEKS & Bank Pundi Indonesia Tbk \\
\hline 14 & BJBR & Bank Jabar Banten Tbk \\
\hline 15 & BJTM & Bank Pembangunan Daerah Jawa Timur (Tbk) \\
\hline 16 & BKSW & Bank Kesawan Tbk \\
\hline
\end{tabular}




\begin{tabular}{|l|l|l|}
\hline 17 & BMRI & Bank Mandiri (Persero) Tbk \\
\hline 18 & BNBA & Bank Bumi Arta Tbk \\
\hline 19 & BNGA & Bank CIMB Niaga Tbk \\
\hline 20 & BNII & Bank Internasional Indonesia Tbk \\
\hline 21 & BNLI & Bank Permata Tbk \\
\hline 22 & BSIM & Bank Sinar Mas Tbk \\
\hline 23 & BSWD & Bank Swadesi Tbk \\
\hline 24 & BTPN & Bank Tabungan Pensiunan Nasional Tbk \\
\hline 26 & INPC & Bank Artha Graha International Tbk \\
\hline 27 & MAYA & Bank Mayapada International Tbk \\
\hline 28 & MCOR & Bank Windu Kentjana International Tbk \\
\hline 29 & MEGA & Bank Mega Tbk \\
\hline 30 & NISP & Bank NISP OCBC Tbk \\
\hline 31 & PNBN & Bank Pan Indonesia Tbk \\
\hline 32 & SDRA & Bank Himpunan Saudara 1906 Tbk \\
\hline
\end{tabular}

